\title{
A VONTADE GERAL E O PAPEL DO LEGISLADOR EM ROUSSEAU
}

Giovani Luiz Zimmermann Jr. ${ }^{1}$

Resumo: O autor genebrino em seu ideal visava construir o novo homem político, que daria origem a uma nova política, capaz de substituir os fundamentos injustos sobre os quais a sociedade foi construída. Para que tudo isso mude é necessário um novo pacto baseado na vontade geral, a qual por sua vez não simplesmente é a soma das vontades particulares uma a uma, mas tão somente retém o suprassumo, isto é, a essência de todas as vontades unidas numa só, cujo maior valor é a vontade coletiva (moral coletiva). Para que haja uma sociedade justa, é necessária a soberania do povo através da vontade geral, sem poderosos e oprimidos, livres ou escravos. Todos os contratantes devem poder agir, sobretudo, com igualdade e liberdade. Essa nova sociedade é aquela que ainda está por ser alcançada. Já não é possível, conservar a condição do estado natural. A desnaturação gesta um novo homem, que passa a viver com os outros e, nessa nova condição, sofrerá mudanças, virtualmente possíveis em seu estado. Na base dessas mudanças está a necessidade primária de criação de um artifício, o "espírito social", assentado sobre uma condição existencial básica. Que condição é essa? É a condição de homem ao mesmo tempo "integrado" (súdito) e "integrante" (cidadão). Buscando garantir a legitimidade da vida social, Rousseau preserva dois valores fundamentais: a liberdade e a igualdade. E pensa ter encontrado a fórmula para o homem que se associa, uma condição que, a seu ver, lhe daria um poder soberano, necessário à salvaguarda desses valores.

Palavras-Chave: Vontade Geral; Legislador; Lei

Abstract: The Genevan author in his ideal aimed at building the new political man, which would lead to a new policy capable of replacing the unrighteous foundations on which society is built. For all this change requires a new covenant based on the general will, which in turn not simply the sum of individual wills one by one, but only retains the acme, that is the essence of all wills united in only, whose greatest value is the collective will (moral collective). So there is a fair society, the sovereignty of the people is required by the general will, without powerful and oppressed, free or slaves. All contractors must be able to act, above all, equality and freedom. This new society is one that is yet to be achieved. It is no longer possible, maintain the condition of the natural state. The denaturation gestated a new man, who happens to live with others, and this new condition, will undergo changes virtually possible in your state. On the basis of these changes is the primary need to create a device, the "social spirit," seated on a basic existential condition. What condition is that? It is the human condition at the same time "integrated" (subject) and "integral" (citizen). Seeking to ensure the legitimacy of social life, Rousseau maintains two fundamental values: freedom and equality. And you think you have found the formula for the man who joins, a condition that, in his view, give him a sovereign power necessary to safeguard these values. Keywords: General will, Legislator, law.

\section{A necessidade da vontade geral no ideal rousseauniano}

Nesta proposta de construir uma sociedade a partir da vontade geral, Rousseau, apresenta uma ideia criativa e original, fundada no entendimento das relações do homem em sociedade. Ele alicerça eticamente o contrato, entendendo a liberdade não motivada por

\footnotetext{
${ }^{1}$ Mestrando em Filosofia pela Universidade Estadual do Oeste do Paraná - UNIOESTE/Toledo. Contato: beteonline1@gmail.com
} 
coações internas, nem por impulsos instintivo/naturais ou desejos momentâneos, mas um contrato que preserve e viabilize o exercício de uma liberdade consciente. Uma das finalidades da vontade geral, é a de convencer o cidadão sem coagir, ao mostrar que a deliberação em prol de um interesse público, beneficia todos os membros da associação, mais do que os objetivos do interesse privado. É por isso que segundo Milton Meira: "Praticar a virtude da justiça é, pois, pautar-se pela vontade geral” (NASCIMENTO, 2012, p. 162).

A vontade geral aqui é pura expressão da liberdade humana, pois ela apresenta uma concepção de justiça não somente como busca da equidade, mas também de equilíbrio social, prevalecendo a vontade do povo. Rousseau revela uma preocupação com a natureza humana no que se refere ao bem viver social e a construção e preservação de sua liberdade. A ideia de bem, identificada na vontade geral, é a sua base, em contraposição à ideia de justiça como equidade. $\mathrm{O}$ caminho para a desagregação social está mais tanto próximo tanto mais quanto na vida associativa cada um mover-se em torno de si próprio, nada restará quando, então, de útil, para entretecer o liame social. Mas o que é a vontade geral? Como ela funcionaria no Estado? O que ela traz de benefício? Quais são suas limitações?

\section{Sobre a Vontade Geral}

O conceito de vontade geral é ao mesmo tempo um dos conceitos mais importantes da filosofia política do Cidadão de Genebra e uma de suas ideias mais mal compreendidas ao longo dos anos. Rousseau realizou a ruptura conceitual da vontade geral divina da tradição escolástica e a colocou no centro do debate político do mundo dos homens; realizou o processo de politização da vontade no centro do cenário político ${ }^{2}$. A noção central de vontade geral em Rousseau aparece pela primeira vez no Discurso sobre a economia política, escrito na mesma época do artigo "Direito natural" de Diderot e publicado no mesmo tomo V da Enciclopédia. É essa, aliás, a tese sustentada por Robert Derathé ${ }^{3}$ em sua introdução ao Discurso sobre a economia política para a edição da Biblioteca da Pléiade das Obras completas de Rousseau. Para Derathé, o Discurso sobre a economia política passa a ter a mesma importância do Manuscrito de Genebra, o papel preparatório do pensamento maduro e definitivo do autor. Pode-se dizer que o sentido da noção de vontade geral no Discurso sobre a economia política é o mesmo que no Contrato social. No Contrato social, o autor faz surgir

\footnotetext{
${ }^{2}$ É nestas condições que afirmamos que o direito político em Rousseau toma uma dimensão mais soberana e democrática. O direito político "não se deduz de fatos: trata-se, segundo Rousseau, de tomar a direção contrária e definir o direito com base nos princípios de uma reflexão ética" (SAHD, 2002, p. 91).

${ }^{3}$ DERATHÉ (1964, p. 74)
} 
o conceito de vontade geral como vontade do corpo político e a principal expressão das leis que definem o justo e o injusto (ROUSSEAU, 1995, p. 244).

Para Junior (2013, p. 93) a vontade geral não é "uma lei específica, nem o conjunto de leis positivas que estejam em vigor, mas a própria possibilidade de fazer e derrubar leis”. Já para Workler (2012, p. 99) ela é a "vontade do corpo político como um todo, sendo a fonte de suas leis e o critério de justiça”. Por outro lado, Simpson (2009, p. 122) descreve a vontade geral como a "vontade própria" de um grupo ou sociedade "independente dos desejos do cidadão". Para Simpson (2009, p. 123) “a vontade geral é nada mais que um julgamento propriamente qualificado e agregado dessa comunidade". Dentro dessas diferentes perspectivas acerca da vontade geral, pensamos que Workler tem a melhor definição, ou a mais completa sobre o que é a vontade geral. Para Rousseau, quando o povo se reúne para deliberar, isto já é a manifestação da vontade geral. O fato de se reunir e deliberar acerca de assuntos pertinentes ao próprio povo isto já é a manifestação da soberania popular. Conforme amplia Workler (2012, p. 97) "é preciso que cada um sirva ao país com sua própria pessoa, e não com seu dinheiro, do contrário o Estado está perdido". Cada membro do soberano (o povo) deveria agir sem levar os demais em consideração, consultando sua própria vontade geral como agente autônomo e assim obedecendo apenas a si mesmo (WORKLER, 2012, p. 101).

A vontade geral é a vontade da pessoa moral, que é o soberano, é enfatizar a relação intrínseca que existe entre vontade geral e bem ou interesse comum, concebido como interseção dos interesses particulares. O corpo político, na condição de um ser moral, é o resultado da união de seres físicos, mas a sua realidade própria, efetiva, é irredutível à realidade física dos seus membros componentes. Talvez o sentido mais imediato do conceito de vontade geral, em Rousseau, apareça em conexão com a ideia de "corpo social". Nessa conexão, a vontade geral não é outra coisa senão a "vontade do corpo político". Como pessoa moral, o soberano teria uma vontade, em sentido análogo ao que ocorre com as pessoas naturais. Na analogia com o corpo, além de ter um limite, ressalta uma diferença constitutiva: a sociedade é composta de pequenos corpos com unidade e vontade geral próprias. Segundo Rousseau no Discurso sobre a Economia Politica:

Toda a sociedade política se compõe de outras sociedades menores de espécies diferentes, cada uma das quais tem seus interesses e máximas; mas essas sociedades, que cada um percebe, porque possuem uma forma exterior e autorizada, não são as únicas que existem realmente no Estado; todos os particulares reunidos por um interesse comum compõem outras tantas, permanentes ou passageiras, cuja força, 
por ser menos aparente, não é menos real, e cujas várias relações, bem observadas, dão o verdadeiro conhecimento dos costumes (ROUSSEAU, 1995, p. 245-246).

Segundo Rousseau, as igrejas, as corporações e todas as organizações presentes no Estado, são sociedades menores que visam reunir um grupo de pessoas sob determinados interesses e objetivos. Mas, seria possível colocá-las em harmonia e encontrar a vontade geral dominante que paira acima de todas elas? É como se a vontade geral representasse um mecanismo cego a equilibrar de modo estrutural a correspondência interna de todas as suas partes e pudesse ser encontrada na lei de um povo já constituído, com uma história, e não em uma consciência animada por representações e por desejos. A vontade geral é a mediação entrem os interesses plurais que interagem na sociedade, assim como afirma Vieira (2004, p. 419):

\begin{abstract}
A posição de Rousseau, todavia, em relação a essa questão, ao admitir a mediação entre a variedade e multiplicidade de interesses existentes na sociedade como condição de atingir-se a vontade geral, abre incontestavelmente a oportunidade, hoje, para os diversos movimentos sociais, não só de manifestarem suas reivindicações e demandas, mas de incorporá-las no esforço coletivo de construção de uma base comum para dirigir "as forças do Estado".
\end{abstract}

Da mesma forma que a vontade particular atua incessantemente contra a vontade geral, o governo também se esforça contrariamente em relação à soberania, e quanto mais esse esforço contrário aumenta, maior é a possibilidade de alteração substancial da Constituição Mas onde poderemos encontrar o lugar-comum que torna a comparação possível e permite alinhar essas vontades a fim de medi-las? É o próprio indivíduo, segundo Rousseau, o espaço apropriado para essa medição; nele as várias vontades gerais se encontram e sugerem uma correspondência entre os interesses compartilhados com os outros indivíduos e, por isso, a contradição inerente a sua própria pessoa, pois ele "pode ser um padre devoto, ou um bravo soldado, ou um pai de família zeloso, e um mau cidadão" (ROUSSEAU, 1995, p. 246). As contradições aparentes observadas em sua conduta e na de tantos homens explicariam esse princípio, como também abririam a possibilidade para encontrar o critério da escolha mais eficaz entre os seus interesses, ou seja, preferir a vontade geral entre os corpos sociais.

Como a vontade geral deve atingir todos os membros aptos do corpo social soberano, ou como ela deve emergir dele e se relacionar com os cidadãos por inteiro, sem nenhuma exceção? A vontade geral, para ser verdadeiramente geral, deve sê-lo tanto no objeto quanto na essência, deve partir de todos para aplicar-se a todos. "Cada um de nós põe em comum sua 
pessoa e todo o seu poder sob a direção suprema da vontade geral, e recebemos, enquanto corpo, cada membro como parte indivisível do todo" (ROUSSEAU, 1999b, p.22). Deter-se em um objetivo particular seria perder a "retidão natural" da vontade geral, e o seu julgamento nesse caso estaria voltado para os interesses alheios aos verdadeiros princípios da equidade. Em última instância, os cidadãos que a compõem perderiam de fato o seu guia, estando reduzidos às ações particulares contrárias aos ideais do corpo político e à sua plena soberania. Para um leitor atento das obras de Rousseau, essa investida contra o geral significa a própria morte do Estado e do seu legítimo detentor, o povo.

Rousseau concebe a vontade geral com base em uma radical transformação social do homem, que envolve a sua completa desnaturalização, e o consequente rompimento com os possíveis laços do ainda presente estado de natureza. Enquanto para Diderot todos, no "silêncio das paixões", podem atingir a vontade geral independentemente do tempo e do lugar, para Rousseau não é certo que possa ser percebida em todas as partes, pois o tempo de sua constituição é bem preciso e limitado. ${ }^{4}$ Mais do que um grande acordo particular, a vontade geral do genebrino apresenta uma outra questão de fundo, a da necessidade da educação cívica ou patriótica para o seu exercício. Rousseau declara que:

A pátria não pode subsistir sem a liberdade, nem a liberdade sem a virtude, nem a virtude sem os cidadãos; tereis tudo se formardes cidadãos; sem isso só tereis maus escravos, começando pelos chefes de Estado. Ora, formar cidadãos não é tarefa para um dia; e para contar com eles quando homens, é preciso instruí-los ainda crianças. (ROUSSEAU, 1995, p. 254)

A educação deverá moldar, sem destruir, as paixões dos homens; deverá, para sermos mais precisos, controlar os seus sentimentos intensos e jamais extinguí-los completamente, porque sem ela não haverá bons cidadãos.

Observamos que o fim pretendido por Rousseau e uma das regras da arte de governar é submeter a vontade particular à vontade geral, tornando o indivíduo um elemento social que se ordena com base nela. Mas como efetivar uma regra tão importante? A resposta de Rousseau é fazendo reinar a virtude!

[...] se quereis que a vontade geral seja cumprida, fazei com que todas as vontades particulares a ela se conformem. E, como a virtude não passa da conformidade da vontade particular à geral, para dizer, numa palavra, a mesma coisa: fazei reinar a virtude. (ROUSSEAU, 1995, p. 294)

\footnotetext{
${ }^{4}$ Para Diderot, a vontade geral pode ser “consultada nos princípios da lei escrita de todas as nações policiadas; nas ações de povos selvagens e bárbaros; nas convenções tácitas inimigos da raça humana entre eles, e mesmo na indignação e no ressentimento, estas duas paixões que a natureza parece ter colocado até nos animais para suprir o defeito das leis sociais e da vingança pública" (DIDEROT, 1876, p. 300).
} 
Só as pessoas honestas sabem obedecer ao governante e exigir dele a manutenção dos bons costumes no seio do povo, e isso é essencial. A vontade geral é sempre, por definição reta, boa, "jamais erra", por estar sempre voltada para o bem comum. Nessa medida, ela tem, efetivamente, uma tendência à infalibilidade. Segundo Rousseau: "a vontade geral é invariavelmente reta e tende sempre à utilidade pública; mas daí não se segue que as deliberações do povo tenham sempre a mesma retidão" (ROUSSEAU, 1999b, p. 37) .

Que o povo sempre "queira o bem”, este é um fato, cuja base é uma versão do antigo princípio de que não se pode desejar senão sub specie boni. As decisões do povo seriam sempre boas, se o que é bom fosse identificado, simplesmente, com essas mesmas decisões. Para Rousseau “deseja-se sempre o próprio bem, mas não é sempre que se pode encontrá-lo. Nunca se corrompe o povo, mas com frequência o enganam, e só então ele parece desejar o mal” (ROUSSEAU, 1999b, p. 37). Para evitar tamanho mal a sociedade, é necessário o auxílio de um "guia" virtuoso chamados por Rousseau de "O legislador" (que abaixo explicaremos).

Para Rousseau, a voz do povo se faz ouvir por intermédio da vontade geral, que se consubstancia nas leis. Mas, como é possível a vontade geral estar sempre certa e as leis por vezes se mostrar equivocada? Segundo Junior $(2013,94)$ "o erro das leis pode advir do fato de o povo nem sempre saber divisar corretamente o que lhe é bom e o que não é”. Este perigo e erro ocorre por influência negativa das facções ou partidos que deturpam os julgamentos humanos, pois tendem a "fazer com que seus membros deliberem todos da mesma forma, fazendo confundir o que é melhor para um pequeno grupo, ou para os governantes, com o que é o bem geral" JUNIOR (2013, p.94). Esse erro geralmente acontece por nos afastarmos do ideal: "que cada um julgue por si mesmo". Para Rousseau, seria necessário que cada cidadão não ecoace "irrefletidamente a opinião de seu vizinho" em uma assembleia pública, mas sim "todos os homens expressando individualmente a própria opinião, sem comunicação entre si, pudessem fazer pender seus juízos independentes [...]” WORKLER (2012, p. 101). Cada membro do soberano deveria agir sem levar os demais em consideração (quanto a influências externas), mas consultando sua própria vontade geral como agente autônomo e assim obedecendo apenas a "si mesmo".

Uma das ideias mais comumente associadas com a democracia é a de que, em um sistema democrático de governo, é o povo que tem a última palavra. Mas será mesmo a voz do povo a voz de Deus? A “voz do povo” é o que deveríamos ser capazes de escutar por trás 
de toda decisão relevante, em um sistema democrático. A decisão coletiva deveria exprimir a vontade geral. Respeitado todo procedimento confiável, aquele que tem seu voto vencido deveria reconhecer sem medo que sua derrota não significaria que seu interesse havia sido desconsiderado ou mesmo prejudicado, mas apenas que sua opinião sobre o que é a vontade geral estaria errada. Satisfeitas essas condições, os mais e os menos que distinguem as vontades particulares seriam mutuamente anulados e o que restaria da soma das diferenças seria a vontade geral.

Para Rousseau, perdemos grande parte de nosso "espírito público", a vontade geral no mundo contemporâneo é muito mais fraca do que a vontade particular, por isso a vontade geral deveria ser reavivada e fortalecida entre os homens para ser retomada a soberania popular e por freios nas forças políticas abusivas. Rousseau percebeu o risco de que o governo abusasse dos poderes que pertencem apenas ao povo, essa é a tendência frequente dos governos, tendência esta de substituir a vontade geral do soberano (povo) por sua vontade particular (governo), isso Rousseau considerava como despotismo (WORKLER, 2012).

Uma constante, ao longo do tratamento que dá Rousseau à ideia de vontade geral, é a sua associação com as noções de bem comum e de interesse geral. O que generaliza a vontade é, efetivamente, o interesse comum que une os membros da associação. O que, afinal, é o interesse comum? Rousseau mais de uma vez observa que sua reconstrução dos princípios do direito político promove a união entre utilidade e justiça, entre aquilo que é vantajoso para o indivíduo e aquilo que é mais justo para a comunidade. Rousseau lembra que o interesse geral se compõe daquilo que é comum aos diversos interesses, aparece aqui a caracterização da vontade geral como soma das diferenças; é o que há de comum entre os interesses que constitui o laço social. Não se entende por vontade geral aquilo que é comum a todos os homens quanto à sua natureza humana, nem aquilo que é da natureza social para qualquer homem em qualquer sociedade, mas aquilo que é o interesse comum, para aqueles indivíduos de cada sociedade em particular. Todo contrato elaborado conforme esta concepção não privilegia uma maioria, mas a unanime vontade de todos os cidadãos contratantes. Segundo Workler (2012, p. 100):

No contrato social, ele o aplica tanto ao interesse público ou bem comum que deve ser promovido pelo soberano de todo Estado, quanto à vontade individual de cada cidadão em alcançar esse bem, amiúde contrário ao interesse particular da mesma pessoa como homem ou membro de outras associações dentro do Estado. 
O que se pede do cidadão, enfim, é que dê sua opinião sobre o que é melhor para o corpo social. Dar sua opinião, nesse caso, significa dar uma interpretação do que seja, no caso particular, o bem comum. Isso implica, naturalmente, que esse bem comum seja, em alguma medida, previamente conhecido. Segundo Cohen (1986, p. 257) "compartilhar uma concepção do bem comum, que, portanto, vai funcionar como o padrão de correção para as decisões". Compartilhar uma concepção do bem comum é um dos principais ingredientes que fazem de um povo, um povo. Isso inclui o vasto e impreciso domínio dos moeurs (o qual, aliás, é terreno privilegiado para a ação do Legislador, que será abaixo explicado), assim como tudo aquilo que cai sob o alcance do amour de la patrie. Para Rousseau, o bem comum é aquilo que é claramente percebido e conhecido pelo Legislador, existe independentemente de todo acordo ou desacordo e anteriormente a toda decisão coletiva. Não é, de fato, a pluralidade dos interesses particulares que põe um problema (na verdade, essa pluralidade é condição da política, reconhece o próprio Rousseau, dentro de certos limites), mas a ausência de interseção entre eles.

Para Rousseau, a unanimidade não é necessária para as decisões coletivas, o que não impede que permaneça como um ideal desejável. Dizer que a unanimidade não é necessária para as decisões coletivas significa dizer que não é necessária para sua legitimidade. Decisões majoritárias, desde que respeitadas as condições em que o sufrágio é confiável, são legítimas. No entanto, dada a desconfiança que Rousseau frequentemente manifesta em relação aos efeitos das dissensões e das divisões, a condição de unanimidade parece desejável para a estabilidade de qualquer comunidade política. A condição de unanimidade pode ser definida como a situação em que os desacordos desaparecem (ou a situação em que os desacordos encontram uma solução). O cidadão cujo voto é vencido pela maioria deve concluir que sua opinião sobre o que é a vontade geral é simplesmente errada. Sua submissão à opinião da maioria, nesse caso e nessas condições, não representa violação da condição de que permaneça "tão livre quanto antes", ou seja, submetendo-se à maioria, a minoria não abre mão da autonomia que a comunidade política está obrigada a preservar. Submeter-se à maioria, nesse caso, não seria diferente de submeter-se à força da verdade. Isso, naturalmente, supõe que se possa confiar em que a maioria vai ser mais apta a ver onde está a verdade sobre a vontade geral.

O processo pelo qual se chega à declaração da vontade geral não é essencialmente um processo de troca de razões, nem um processo de barganha, de negociação, de acomodação de interesses. Rousseau parece ter adquirido, à medida que aprofundava sua compreensão dos 
princípios do direito político, uma consciência cada vez mais aguda da grande fragilidade da saúde dos corpos políticos. O processo deliberativo, segundo Rousseau, é uma consulta individual à consciência. Ouvir a voz da consciência, do "espírito público" que está sempre voltada para o bem, é o ponto fundamental. Vemos aqui a importância da religião civil (assunto que abordaremos no segundo capítulo desta dissertação) na formação moral do indivíduo, nos sentimentos de sociabilidade e nessa preparação do cidadão em seu exercício da soberania popular.

\section{Sobre o Papel do Legislador}

Mas como conciliar a soberania popular e as leis? Como o povo poderá manifestar sua vontade geral sem precisar delegá-la a representantes? No Contrato Social, distinguindo a tarefa de redigir as leis, do direito de as votar (ato soberano do povo), Rousseau traz a tona a necessidade da figura ímpar do Legislador. A seu ver, a elaboração das leis deve obedecer a uma inspiração única, que tudo faça concorrer para a realização do "espírito social". Nas palavras de Rousseau:

\footnotetext{
Todos precisam igualmente de guias. É preciso obrigar uns a conformar suas vontades à sua razão; é preciso ensinar ao outro a conhecer o que quer. Assim, das luzes públicas resulta a união do entendimento e da vontade no corpo social, daí o exato concurso das partes e, enfim, a maior força do todo. Eis de onde nasce a necessidade de um Legislador. (ROUSSEAU, 1999b, p. 49)
}

Observamos no texto acima a descrição daquilo que é uma das tarefas mais importantes do Legislador, tarefa esta de dar uma formulação clara para este padrão de nossos juízos, tomando como base a vontade geral. Cabe ao Legislador encontrar uma formulação clara das condições que tornam possíveis a preservação do corpo social. Segundo Workler (2012, p. 111) "a função dos legisladores não era exercer o poder, mas apenas promover, em forma de sublime sedução, a apoteose do intelecto e do espírito público dos cidadãos comuns".

Esse sujeito extraordinário, deve conhecer profundamente a natureza humana e suas paixões, mas que o mesmo não se deixe influenciar por nenhuma paixão. Ele se apresenta como intérprete da palavra divina, persuade sem convencer. Seu encargo não é o de governo, nem o do soberano. Mas como Prometeu ao conceber a dádiva do fogo a humanidade, ele possibilita a transfiguração moral dos homens. Ao legislar que seja um homem capaz de transformar a natureza humana e de contribuir para que a condição isolada e originária do homem seja substituída gradualmente, por uma condição moral e civil. Segundo Workler 
(2012, p. 110) cabe ao Legislador "transformar as pessoas solitárias em partes integrantes de um conjunto muito maior, de onde os cidadãos receberiam vida e existência".

O Legislador deve se empenhar na direção de aperfeiçoar os que são potencialmente adequados à condição social e a prática de virtude, desestimulando aqueles que são favoráveis ao surgimento dos vícios civis. Como dizia Aristóteles: "É da inteligência e da coragem que depende a aptidão para a vida civil; certamente, elas são necessárias para a instituição de um legislador que queira estabelecer o reinado da virtude" (ARISTÓTELES, 2006, p. 146).

Há, de fato, um espaço inabalável para a atuação das paixões nas deliberações da vontade geral. Mas, como transformar essas paixões? Eis a tarefa do legislador. É ele quem irá propor as regras para a formação do cidadão ao canalizar as energias negativas do amorpróprio ao amor à pátria, ou seja, aliar essa paixão imperturbável do indivíduo com o doce sentimento do bem comum, tornando-a uma invencível paixão pela mãe-pátria. O Legislador é “[...] o mecânico que inventa a máquina” (ROUSSEAU, 1999b, p. 50). O Legislador é um dos elementos mais distintos e paradoxais da teoria da vontade geral até a esfera da execução (governo), já que a condição última da legitimidade do poder político se dá pelo critério da não representatividade. Porém “[...] é nesse nível que surgem todos os problemas do 'paradoxo do Legislador', a essa necessária representação por parte do Legislador de uma vontade geral necessariamente não representável" (FORTES, 1997, p. 116). Ao mesmo tempo em que o Legislador é encarregado de "conservar" o corpo político, pois o corpo político começa a morrer a partir do momento que nasce, é também incumbido de "destruir o edifício" de certas convenções sociais e extirpar os vícios civis que possam surgir.

O papel do Legislador vai ser justamente o de formador de interesses. Não apenas dar uma formulação, mas uma articulação visível do que seja o bem comum. Ele também cria condições para que a interseção dos interesses seja a mais ampla possível. O Legislador possui o poder de criar leis? Claro que não. Se assim o fizesse, tomaria o poder soberano (que pertence ao povo) em suas mãos, contrariando o princípio originário da Soberania rousseauniana. Como foi ele próprio (o povo) que a estabeleceu. Segundo Rousseau: "Aquele que redige as leis não tem, portanto, ou não deve ter nenhum direito legislativo e, nem o próprio povo pode, quando o quiser, despojar-se desse direito intransferível [...]" (ROUSSEAU (1999b, p. 51). O Legislador por ter a responsabilidade de dar à expressão da vontade geral do povo um substrato racional e afirmativo, "representa" as deliberações populares sem nenhuma autoridade e sem nenhum poder representativo, como se fosse um mero "transportador" das aclamações públicas da vontade geral. Segundo Simpson (2009, p. 
157) O legislador "estabelece as condições da sociedade política, mas não tem autoridade para sancionar as leis na sociedade". O lugar que o Legislador ocupa na teoria rousseauniana é o de "guia", o termo médio que transporta as manifestações públicas da vontade geral até a sua ratificação em leis passíveis de deliberação popular.

Respeitada a correlação direitos/deveres, constituindo-se um "liame social” sólido, está então garantida a preservação do corpo politico e a liberdade civil de cada indivíduo. $\mathrm{O}$ pressuposto dessa solidez é a subordinação do interesse particular ao interesse público, alcançada em primeiro lugar por meio da formação de costumes sadios. Nesse novo contexto cada associado exerce dois papéis, como homem e como cidadão. O mesmo indivíduo que faz a lei no exercício da cidadania, cumpre-a na qualidade de súdito. O Legislador surge no cenário político mediando esta passagem da expressão da vontade geral até a sua racionalização em leis. O Legislador é aquele capaz de redigir as leis; mas não como uma atividade maquinal pela pura e simples observação da manifestação da vontade geral. Ele precisa ser essa espécie de termo médio entre o povo e governo; antes de redigir boas leis em si mesmas, deve observar com cuidado se o povo está apto para recebê-las. "[...] legislador sábio não começa redigindo leis ao acaso, mas antes, examina se o povo a quem elas são destinadas tem condição de suportá-las" (ROUSSEAU, 1964, p. 318). O Legislador deve levar em consideração as características culturais, sociais e geográficas para redigir leis aceitáveis para o povo; precisa conhecer a natureza do campo político em que atua e a função social do espaço político na qual está inserido. Conforme descreve Nascimento:

\footnotetext{
Esse percurso do legislador ao escritor político é, na verdade, um exercício muito bem calculado para inserir o legislador no espaço político, por intermédio de alguém que, ao mesmo tempo em que oferece os códigos para a intervenção do fundador, tem também todas as condições para perpetuar sua obra, exatamente porque se situa num lugar privilegiado, o de ser a peça mais importante na arquitetura do edifício político (NASCIMENTO, 2012, p. 157).
}

Nesta construção do edifício político rousseauniano observamos que pode ocorrer um entrave para a aceitação geral das leis pelo povo: os costumes interferindo no grau de aceitabilidade das leis. Rousseau não duvida da capacidade do povo em fazer boas escolhas, mas faz uma reflexão crítica, sobre quais são os fatores que frequentemente interferem na “cegueira" de uma multidão. Quais são esses fatores? Interesses privados e a opinião pública podem estar significativamente distorcidos, fazendo com que o povo acredite estar sendo atendido, quando na prática, está tomando para si a vontade das facções e de lideranças inescrupulosas. 
O Legislador precisa conhecer todos os interesses e não se deixar influenciar por nenhum. Deve estar acima dos conflitos, porque representa "[...] o grau mais alto da compreensão de um corpo social a respeito de si mesmo [...]" (MONTEAGUDO, 2006, p. 13). Para que as leis redigidas pelo Legislador possam surtir o devido efeito na comunidade política, estas precisam revelar características locais dentro das necessidades populares. Nas palavras do autor genebrino:

Que povo é apropriado para a legislação? Aquele que nunca esteve sob o jugo das
leis, que não tenha superstições ou costumes enraizados, mas que já esteja vinculado
por certa união de origem ou de interesse. [...] Aquele que não é nem rico nem
pobre, que é suficiente em si mesmo. Em uma palavra, que reúna a consistência de
um povo antigo com a docilidade de um povo jovem (ROUSSEAU, 1964, p. 325).

Para o autor genebrino, existe certo período de "maturação" de um povo, no qual os costumes não estejam muito arraigados a ponto de influenciar na elaboração das leis. Outra necessidade é que os preconceitos não estejam muito enraizados, sob a ameaça de comprometer o estabelecimento das leis na sociedade. O Legislador, não pode sob as mesmas circunstâncias, fazer leis apenas tomando os homens como podem ser, mas, sobretudo, tomando a consciência daquilo que eles são a partir de suas realidades concretas. Todos que legislam, devem se orientar pelos princípios da liberdade, da igualdade, do bem comum e da vontade geral. O Legislador necessita se colocar imparcialmente no lado mais equânime, tomando como critério o bem comum, na busca de garantir, através da melhor forma possível, a liberdade e a igualdade de fato na comunidade política. O Legislador também precisa considerar a necessidade das instituições políticas. Movido pelo desejo de unir os homens, deve indagar em sua atividade quais aquelas que a comunidade política necessita para garantir a efetividade das leis. Para Rousseau (1999b, p. 53) "o verdadeiro político admira em suas instituições o grande e poderoso gênio que preside aos estabelecimentos duradouros". O Legislador é o guia que tentará melhor conduzir os anseios soberanos do povo e canalizá-los em direção as leis. Ele precisa pensar os meios de aplicação e a procedimentalidade de uma lei ao redigi-la. Referindo-se a ideia de Estado de Rosseau, ideia intimamente relacionada com sua concepção de política, Cassirer (1999, p. 63) assim afirma:

Rousseau de modo algum vê no Estado uma mera associação, uma comunidade de interesses e nem um equilíbrio dos interesses de vontades isoladas. O Estado não é, segundo ele, um mero sumário empírico de determinados impulsos e inclinações, de determinadas veleidades, mas é a forma na qual a vontade, enquanto vontade moral, realmente existe. A lei em seu sentido puro e rigoroso não é um fio que se junta de maneira puramente exterior às vontades individuais impedindo que se separem; ela é, ao contrário, o princípio constitutivo; é o que as fundamenta e justifica 
espiritualmente. Ela pretende dominar os cidadãos a medida que, em cada ato individual, ao mesmo tempo os torna cidadãos e os educa para serem cidadãos.

O Estado proposto por Rousseau é fundado em uma sociedade em que a política e a lei se tornam instrumentos pedagógicos na educação do cidadão. A política é vista também como um meio de construção do homem moral. Nesta construção do homem moral, Rousseau reconhece (dentro de seus limites) a importância da Religião na formação do cidadão virtuoso.

\section{Política e Religião}

Assim como os costumes, a religião opera de forma semelhante na esfera civil. A política e a religião podem até estabelecer entre ambas um objeto comum de interesse, mas em muitas ocasiões, o que ocorreu na fundação dos Estados foi que uma serviu de instrumento para outra. Segundo Rousseau:

\footnotetext{
Eis o que obrigou, em todos os tempos, os pais das nações a recorrerem à intervenção celeste e a honrar os deuses [...] a fim de que os povos, submetidos às leis do Estado como às da natureza, e reconhecendo o mesmo poder na formação do homem, e na da cidade, obedeçam com liberdade e aceitem docilmente o julgo da felicidade pública" (ROUSSEAU, 1999b, p. 52)
}

Para o cidadão de genebra, a esfera da religião não pode ultrapassar as fronteiras da utilidade pública. Rousseau reconhece que em todos os tempos os "pais das nações" ou seja, as lideranças políticas utilizaram-se da religião na organização social das cidades e nações, bem como também utilizaram-se de pressupostos religiosos ou divinos na criação, explicação e absorção das leis pelos indivíduos. O autor genebrino apesar de reconhecer sua utilidade, separa a religião da política (coloca cada uma em seu papel), pois sabia que o fenômeno da intolerância religiosa promovido pelo fanatismo é fruto da não observância da parte dos cidadãos a estes limites. Para Rousseau, aquilo que acarreta prejuízos à unidade social, de nada vale. O homem deve estar habilitado a adaptar-se às leis civis do país que escolher como pátria; cidadão do mundo, contudo, guiar-se-á, em última análise, pelas leis escritas em seu coração (um tipo de consciência moral coletiva). A correspondência entre a moralidade que deve regular a vida interior do indivíduo e a legalidade que tutela o cidadão será tanto mais imperfeita quanto imperfeitas forem as leis da pátria onde se vive.

Reconhecendo sempre que a liberdade do homem civil é relativa a uma comunidade ética e política. A legislação deve educar o povo em suas deliberações e incitar o interesse em ser justo através das leis, para que os cidadãos assim possam verificar a utilidade pública, 
percebendo a necessidade de serem membros ativos no Estado. É necessário um princípio de reciprocidade jurídica, constituído por meio da união entre "as convenções sociais e as leis civis (associando os direitos aos deveres), fazendo com que a justiça alcance seu objetivo final, a manutenção da liberdade e da igualdade de fato" (JACQUES, 2015, p. 60). Na história, a legislação romana é o melhor exemplo desse feito, em que o amor dos cidadãos uns pelos outros e o respeito ao nome davam a coragem necessária e o ânimo suficiente à virtude deles. Que a pátria se mostre como uma "mãe comum", querida pelos seus filhos, os cidadãos, quando estes usufruem as vantagens oferecidas, e o governo permita a participação deles na administração pública para que se sintam em casa respeitando as leis como a fiança da liberdade comum. Assim estarão garantidas a indissolubilidade do Estado e a manutenção dos bons costumes, do respeito às leis, do amor à pátria e do vigor cada vez maior da vontade geral.

A arte de legislar, segundo o autor genebrino, consiste na descoberta da proporção exata entre a força do governo e a vontade dos membros da comunidade, buscando nesta relação, a maneira mais vantajosa de organizar o Estado. A opinião pública deve apresentar preceitos que busquem unir a identidade nacional com os bons costumes, desestimulando aqueles que são perniciosos à sociabilidade como um todo. "As opiniões de um povo nascem de sua Constituição. Conquanto, a lei não rege os costumes, é a legislação que os faz nascer [...]” (ROUSSEAU, 1999b, p. 153). Para Rousseau, a divisão destas leis, precisa seguir quatro esferas fundamentais: das leis políticas (corpo político com o todo e a si mesmo), das leis civis (se relacionam com os membros da comunidade entre si e com o corpo político), das leis criminais (relação entre o homem e a lei), e por fim, das leis relativas aos costumes e a opinião pública (influencia na escolha e no modo de vida dos indivíduos na esfera social). A Constituição deve abranger leis possíveis de serem efetivadas pelos cidadãos tomando como medida o grau de aperfeiçoamento dos costumes, não em leis idealmente perfeitas que não dialogam com as condições objetivas de um povo JACQUES (2015). A Constituição é esse caminho possível, que tem o desafio de modelar os costumes dos indivíduos e extirpar preconceitos sociais.

\section{REFERÊNCIAS}

CASSIRER, Ernst. A questão Jean-Jacques Rousseau. Tradução de Erlon José Paschoal e Jézio Gutierrez. São Paulo: Editora UNESP, 1999. 
CARDOSO, Sérgio. Do Desejo à Vontade: A constituição da sociedade política em Rousseau. Revista Discurso, v.5, n.6, (1975)

CHAUÍ, Marilena. Convite a Filosofia. Ed. Ática, São Paulo, ano 2000 Introdução à história da filosofia: as escolas helenísticas, v. II / Marilena Chaui. São Paulo: Companhia das Letras, 2010

COHEN, Joshua. Reflections on Rousseau: and Public Affairs, v. 15, n. 3, 1986 b.

CUNHA, Luiz A. Sociedade, Estado e Educação. In: Revista Brasileira de Educação. São Paulo: $\mathbf{n}^{0} .1,1996$.

DALBOSCO, Claudio Almir. Crítica à cultura, sociabilidade moral e amour de l'ordre em Rousseau. Contexto \& Educação, Ano 24, no 82, Jul./Dez, Ijuí: Editora Unijuí, 2009, p 13 à 33 .

DENT, N. J. H. Dicionário Rousseau. Tradução Álvaro Cabral. Rio de Janeiro: Jorge Zahar Editor, 1996. (Col. Dicionário de Filosofia).

DERATHÉ, Robert. Jean-Jacques Rousseau et la science politique de son temps. Paris, Vrin, 1970.

DERATHÉ, Robert. Notes et variantes. Du contrat social”, en Jean-Jacques Rousseau Oeuvres complètes, v. 3, 1964.

FREITAS, Jacira de. Abstração de valor e independência econômica: Rousseau e a crítica ao dinheiro. Revista de Filosofia Argumentos, ano 4, no 8, 2012, p. 78 - 101.

FORTES, Luiz Roberto Salinas. Rousseau: da Teoria à Prática. São Paulo: Ática, 1976.

HOBBES, T. De Cive. Petrópolis: Vozes, 1993

JACQUES, Luís Fernando. A concepção de direito político em Rousseau : o problema da elaboração da constituição e o papel do legislador. Tese de Mestrado, UNIOESTE, Toledo, PR : [s. n.], 2015.

JÚNIOR, José Benedito de Almeida. Como ler Jean-Jacques Rousseau. São Paulo: Paulus, 2013.

LOCKE, John. Two treatsises of civil government. London, Everyman's Library, 1966.

MONTEAGUDO, Ricardo. Rousseau existencialista. In: Trans/Form/Ação. Marília: vol.27, $n^{0} .1,2004$

NASCIMENTO, Milton M. O contrato social: entre a escala e o programa. In: Discurso. São Paulo: 1988

PAIVA, Wilson Alves de. Natureza e natureza: dois conceitos complementares. Revista

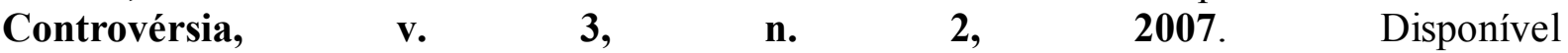
em:http://revistas.unisinos.br/index.php/controversia/article/view/7048 
REALE, Giovanni e ANTISERI, Dario. História da filosofia: do humanismo a Kant. Vol. II. S/T. 2. ed. São Paulo: Paulus, 1990. (Coleção Filosofia).

ROLland, R. O Pensamento vivo de Rousseau. Trad. J. Cruz Costa. São Paulo: Ed. da USP, 1975.

ROUSSEAU, Jean-Jacques. Discurso sobre a origem e os fundamentos entre a desigualdade entre os homens: precedido de discurso sobre as ciências e as artes (DD). Tradução de Maria Ermantina de Almeida Prado Galvão, 2o Edição, São Paulo: Martins Fontes, 1999a.

. Manuscrito de Genebra (MG). In Obras políticas, Porto Alegre: Globo, 1962

. O Contrato Social (CS). Tradução de Antônio de Pádua Danesi, 3a Edição, São Paulo: Martins Fontes, 1999b

Discurso sobre economia política. Tradução de Maria Constança Peres Pissara; prefácio de Bento Prado Jr. Clássicos do pensamento político; 15. Petrópolis: Vozes. 1995.

SAHD, Luiz Felipe Netto de Andrade e Silva. A consciência cívica no pensamento político de Rousseau. Educação e Filosofia, v. 16, no 31. Campinas, 2002

$\overline{\text { Kriterion, vol. 48, }}{ }^{\circ}$ 115. Belo Horizonte, 2007.

"Considerações sobre o fundamento moral da propriedade". In:

SILVA, Vital. Rousseau: Da liberdade natural à Liberdade Civil. Saberes em perspectiva, v.1, n.1, 2011.

SIMPSON, Matthew. Compreender Rousseau; tradução de Hélio Magri Filho. Petrópolis: Vozes, 2009.

STAROBINSKI, Jean. Jean-Jacques Rousseau: a transparência e o obstáculo. São Paulo: Cia das Letras, 1991

STRAUSS, Leo. Droit naturel et histoire. Traduzido do inglês por Monique Nathan e Éric de Dampierre. Paris: Champs-Flammarion, 1986.

VIEIRA, Luiz Vicente. Os movimentos sociais e o espaço autônomo do político: o resgate de um conceito a partir de Rousseau e Carl Schmitt. Coleção Filosofia, no 167, Porto Alegre: EDIPUCS, 2004, 432 p.

WORKLER, Robert. Rousseau; tradução de Denise Bottmann. Porto Alegre: L\&PM, 2012.

YOLTON, John W. Dicionário Locke. Tradução de Álvaro Cabral. Rio de Janeiro: Jorge Zahar, 1996 